\title{
A STUDY OF PREVALENCE OF OCULAR MORBIDITIES IN SCHOOL GOING CHILDREN IN A RURAL DISTRICT OF MANIPUR
}

\author{
Rajkumari Bigyabati1, Rajkumar Victor², Bishwalata Rajkumari ${ }^{3}$
}

${ }^{1}$ Assistant Professor, Department of Ophthalmology, Jawaharlal Nehru Institute of Medical Sciences, Imphal.

2Senior Resident, Department of Ophthalmology Jawaharlal Nehru Institute of Medical Sciences, Imphal.

${ }^{3}$ Associate Professor, Department of Community Medicine, Jawaharlal Nehru Institute of Medical Sciences, Imphal.

\begin{abstract}
\section{BACKGROUND}

Children are affected by various eye disorders like refractive error, eye infections, and squint. Uncorrected refractive errors are a common, but avoidable problem. The presence of uncorrected refractive error in children has a considerable impact on their physical, mental, and behavioural development. Early detection and timely intervention can improve a child's potential tremendously during the formative years.
\end{abstract}

\begin{abstract}
AIM
To find out the magnitude of ocular morbidities among school children of Thoubal, a rural District of Manipur and the type of refractive error prevalent in that region.
\end{abstract}

\section{METHODS}

A cross sectional study was conducted among school children of Thoubal, a rural area of Manipur. Excluding absentees and non-responders, students were examined by trained Ophthalmologists and Ophthalmic Assistants. Visual acuity was assessed in all students using Snellen's chart and refraction performed when required. Patients with no improvement by the above method were further examined at the tertiary hospital. Data was tabulated and analysed.

\section{RESULTS}

A total of 1700 students aged from 5 to 15 were examined out of which $53 \%$ were boys and $47 \%$ girls. Prevalence of ocular morbidity was $17.7 \%$ of which refractive error was found in $16.4 \%$, cataract in $0.1 \%$, squint in $0.1 \%$, corneal opacity in $0.1 \%$, chalazion/stye in $0.4 \%$, conjunctivitis in $0.3 \%$, and blindness in $0.1 \%$. A significant proportion of girls suffer from refractive error (57\%) as compared to boys (43\%). Refractive errors prevail highest among the age group 10-12 years. Astigmatism was the most common refractive error (48\%) followed by Myopia (34\%) and Hypermetropia (18\%).

\section{CONCLUSION}

The study concludes that vision screening in school children is very useful in early detection of refractive errors and other ocular morbidities leading to early treatment and prevention of development of visual disability and amblyopia as most of the children were unaware of the problem.

\section{KEYWORDS}

Children, Prevalence, Ocular, Morbidity, Refractive Error.

HOW TO CITE THIS ARTICLE: Bigyabati R, Victor R, Rajkumari B. A study of prevalence of ocular morbidities in school going children in a rural district of Manipur. J. Evolution Med. Dent. Sci. 2016;5(53):3540-3543, DOI: 10.14260/jemds/2016/816

\section{INTRODUCTION}

Ocular morbidity in children affects the learning ability and has a negative influence on development and maturity. Refractive error is an optical defect intrinsic to the eye, which prevents light from being brought to a single focus on the retina thus reducing good vision.[1] Refractive errors are the second major cause of blindness in India after cataract. Children form one of the main age groups requiring attention to refractive error because of its high prevalence. Most school going children are not aware of their disability and try to adjust to their poor sight. Only those children whose

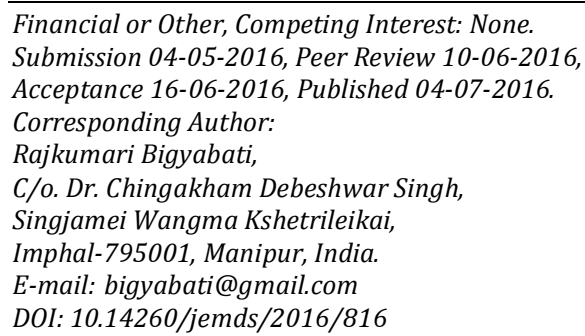

disabilities are so severe as to be noticed by parents or teachers are brought to an Ophthalmologist for evaluation. Refractive errors are easily correctable and if left untreated can result in amblyopia and strabismus.

Childhood blindness and visual impairment are more disabling than adult-onset blindness because of the long span of life still remaining to be lived. School-age children constitute a particularly vulnerable group where uncorrected refractive errors may have a dramatic impact on learning capability and educational potential. Data on prevalence and causes of blindness and severe visual impairment in children are necessary for planning preventive and curative services for children. It is estimated that there are 1.4 million blind children in the world. An additional 7 million suffer from low vision and a further 10 million children have correctable refractive error causing visual impairment. It is estimated that the prevalence of blindness in India is $0.8 / 1000$ children in the age group 0-15 years.[2] Among the blind persons in India $30 \%$ of them lose their eyesight before the age of 20 years and many of them are under five signifying the 
importance of early detection and treatment of ocular disease and visual impairment among young children.[3]

Integration of vision screening and refractive services for school students within screening for other health issues is target for control of blindness in children in VISION 2020THE RIGHT TO SIGHT.[4] The Refractive Error Study in Children (RESC) has been formed under this initiative to try and assess the prevalence of refractive errors in children.[5] The magnitude of refractive error is different in the urban and rural areas of India.[6] The aim of this study is to assess the magnitude of refractive error and other ocular morbidities in school children in a rural area of Manipur as no data is available in this context from this part of India.

\section{MATERIALS AND METHODS}

This cross sectional study was conducted among school children of Thoubal District, a rural area of Manipur, which is a North-Eastern State of India. Thoubal is one of the valley districts of Manipur with a population of 4, 21, 517 and located at a distance of 25 kilometres from Imphal, the capital of Manipur. Majority of population belong to middle and lower socioeconomic group. Our study population includes all school children residing in the rural areas of Thoubal District. Refusal to participate and students absent on the day of visit were excluded from the study.

\section{Sample Size Calculation and Sampling}

Sample size was calculated based on a prevalence of refractive error of $8 \%$ among rural school children.[7] Using $1.5 \%$ precision and a $5 \%$ significance level a sample size of 1257 was calculated. Assuming a little more than $10 \%$ nonresponders, the sample size was increased to 1383 rounded off to 1700.

\section{Sampling Design}

From the list of high schools located in rural areas of the district, the schools were sampled sequentially using lottery method and all eligible students in the selected schools were included. A total 5 (Five) schools were selected till the required sample size was reached.

\section{Operational Definition}

Visual acuity $<6 / 6$ was taken as criteria of defective vision because criteria of low vision according to WHO (VA <6/18 in better eye) is grossly subnormal for school children. ${ }^{[8]}$

\section{Procedure}

After obtaining verbal informed consent from children and parents/guardians, the socio-demographic profile of the children were recorded in a structured proforma. Vision was recorded with a Snellen's chart at a distance of 6 metres. Visual acuity $<6 / 6$ was taken as criteria of defective vision. If the distant visual acuity was $<6 / 6$ those students were subjected to refraction. Refraction was done by subjective and objective methods and appropriate spectacles prescribed. Students with no improvement by the above methods and those with other ocular morbidities were referred to the tertiary hospital for further evaluation.

\section{Statistical Analysis}

Descriptive statistics were generated using mean, proportions, percentages, and standard deviation. Analytical statistics like chi-square test were used. A p-value of $<0.05$ was taken to be significant.

\section{Ethical Issues}

Ethical clearance was obtained from the Institutional Ethical Committee. Prior permission from school authorities were obtained for the visits. Purpose of visit was explained and verbal informed consent was obtained from students as well as guardians and strict confidentiality was maintained.

\section{RESULTS}

Five schools were visited and 1921 students were selected for the study. A total of 151 students were absent on the day of visit and 1770 students were examined. Therefore the students' response rate was $92.1 \%$. Among the participants, $53 \%$ were boys and $47 \%$ girls (Table 1 ). Students from age of 5 to 15 studying in class 1 to 10 were examined out of which ocular morbidity was seen in $17.7 \%$. Ocular morbidity prevails highest among the age group 10-12 years (Table 1). Defective vision of visual acuity between $<6 / 6$ to $6 / 12$ was seen in $9.1 \%$ of students, low vision of visual acuity between $6 / 18$ to $6 / 60$ was seen in $4 \%$ of students and very low vision to no PL was seen in $0.1 \%$ (Table 1 ).

Refractive error was the commonest ocular morbidity and found in $16.45 \%$, cataract in $0.1 \%$, squint in $0.1 \%$, corneal opacity in $0.1 \%$, chalazion/stye in $0.4 \%$, conjunctivitis in $0.3 \%$, and blindness in $0.1 \%$ (Table 2). A significant proportion of girls suffer from refractive error $(57 \%)$ as compared to boys (Table 3). Among those having refractive error, $98 \%$ could be corrected by prescribing glasses (Table 1). The refractive errors in girls could be corrected by prescribing glasses whereas some of the refractive errors in some boys could not be corrected by prescription of glasses (Table 4). Astigmatism (48\%) was the most common refractive error followed by myopia (34\%) and hypermetropia was the least common with a prevalence of $18 \%$ (Table 5).

\begin{tabular}{|c|c|c|c|}
\hline Variable & & No. & $\%$ \\
\hline \multirow{2}{*}{ Gender } & Male & 956 & 53 \\
\hline & Female & 814 & 47 \\
\hline \multirow{4}{*}{$\begin{array}{l}\text { Age Group } \\
\text { (Yrs.) }\end{array}$} & $4-6$ & 174 & 9.8 \\
\hline & $7-9$ & 546 & 30.8 \\
\hline & $10-12$ & 769 & 43.4 \\
\hline & $>12$ & 281 & 15.9 \\
\hline \multirow{4}{*}{$\begin{array}{l}\text { Vision } \\
\text { (Rt Eye) }\end{array}$} & Normal & 1544 & 87.2 \\
\hline & $<6 / 6$ to $6 / 12$ & 159 & 9.0 \\
\hline & $6 / 18$ to $6 / 60$ & 66 & 3.7 \\
\hline & Very low vision to No PL & 1 & 0.1 \\
\hline \multirow{4}{*}{$\begin{array}{l}\text { Vision } \\
\text { (Lt Eye) }\end{array}$} & Normal & 1528 & 86.3 \\
\hline & $<6 / 6$ to $6 / 12$ & 165 & 9.3 \\
\hline & $6 / 18$ to $6 / 60$ & 76 & 4.3 \\
\hline & Very low vision to No PL & 1 & 0.1 \\
\hline \multirow{3}{*}{$\begin{array}{l}\text { Refraction } \\
\text { (Rt eye) }\end{array}$} & No need for correction & 1503 & 84.9 \\
\hline & Correction with glasses & 265 & 15.0 \\
\hline & $\begin{array}{l}\text { Cannot be corrected with } \\
\text { glasses }\end{array}$ & 2 & 0.1 \\
\hline \multirow{3}{*}{$\begin{array}{l}\text { Refraction } \\
\text { (Lt eye) }\end{array}$} & No need for correction & 1487 & 84.0 \\
\hline & Correction with glasses & 278 & 15.7 \\
\hline & $\begin{array}{l}\text { Cannot be corrected with } \\
\text { glasses }\end{array}$ & 5 & 0.3 \\
\hline
\end{tabular}




\begin{tabular}{|c|c|c|}
\hline Findings & Number & Percentage \\
\hline Normal & 1456 & 82.3 \\
\hline Refractive error & 208 & 11.8 \\
\hline Cataract & 2 & 0.1 \\
\hline Squint & 2 & 0.1 \\
\hline Corneal ulcer/opacity & 2 & 0.1 \\
\hline Chalazion/Stye & 6 & 0.4 \\
\hline Conjunctivitis & 4 & 0.3 \\
\hline Blindness & 2 & 0.1 \\
\hline Table 2: Associated Ocular Morbidity Among Students \\
\hline
\end{tabular}

\begin{tabular}{|c|c|c|c|c|}
\hline \multirow{2}{*}{ Variable } & \multirow{2}{*}{ Categories } & \multicolumn{2}{|c|}{ Gender } & \multirow{2}{*}{ P } \\
\cline { 3 - 4 } & & $\begin{array}{c}\text { Male, } \\
\text { N (\%) }\end{array}$ & $\begin{array}{c}\text { Female, } \\
\text { N (\%) }\end{array}$ & \\
\hline \multirow{3}{*}{$\begin{array}{c}\text { Right Eye } \\
\text { vision }\end{array}$} & Normal & $\begin{array}{c}860 \\
(55.7)\end{array}$ & $\begin{array}{c}684 \\
(44.3)\end{array}$ & \multirow{2}{*}{0.000} \\
\cline { 2 - 4 } & $\begin{array}{c}\text { Refractive } \\
\text { error }\end{array}$ & $\begin{array}{c}96 \\
(42.4)\end{array}$ & $\begin{array}{c}130 \\
(58.6)\end{array}$ & \\
\hline \multirow{2}{*}{$\begin{array}{c}\text { Left Eye } \\
\text { vision }\end{array}$} & Normal & $\begin{array}{c}850 \\
(55.6)\end{array}$ & $\begin{array}{c}678 \\
(44.4)\end{array}$ & \multirow{2}{*}{0.001} \\
\cline { 2 - 4 } & $\begin{array}{c}\text { Refractive } \\
\text { error }\end{array}$ & $\begin{array}{c}106 \\
(43.8)\end{array}$ & $\begin{array}{c}136 \\
(56.2)\end{array}$ & \\
\hline \multicolumn{4}{|c|}{ Table 3: Comparison of Vision by Gender Among the } \\
Students (N=1770) \\
\hline
\end{tabular}

\begin{tabular}{|c|c|c|c|c|}
\hline \multirow[b]{2}{*}{ Variable } & \multirow[b]{2}{*}{ Categories } & \multicolumn{2}{|c|}{ Gender } & \multirow{2}{*}{$\begin{array}{c}P \\
\text { value }\end{array}$} \\
\hline & & $\begin{array}{l}\text { Male, } \\
\text { N (\%) }\end{array}$ & $\begin{array}{c}\text { Female, } \\
\text { N (\%) }\end{array}$ & \\
\hline \multirow{3}{*}{$\begin{array}{l}\text { Right Eye } \\
\text { refraction }\end{array}$} & $\begin{array}{l}\text { No need for } \\
\text { correction }\end{array}$ & $\begin{array}{c}832 \\
(55.4)\end{array}$ & $\begin{array}{c}671 \\
(44.6)\end{array}$ & \multirow{3}{*}{$0.008^{*}$} \\
\hline & $\begin{array}{c}\text { Correction } \\
\text { with glasses }\end{array}$ & $\begin{array}{c}122 \\
(46.0)\end{array}$ & $\begin{array}{c}143 \\
(54.0)\end{array}$ & \\
\hline & $\begin{array}{l}\text { Cannot be } \\
\text { corrected with } \\
\text { glasses }\end{array}$ & $\begin{array}{c}2 \\
(100.0)\end{array}$ & $0(0)$ & \\
\hline \multirow{3}{*}{$\begin{array}{l}\text { Left Eye } \\
\text { refraction }\end{array}$} & $\begin{array}{l}\text { No need for } \\
\text { correction }\end{array}$ & $\begin{array}{c}826 \\
(55.5)\end{array}$ & $\begin{array}{c}661 \\
(44.5)\end{array}$ & \multirow{3}{*}{$0.001^{*}$} \\
\hline & $\begin{array}{c}\text { Correction } \\
\text { with glasses } \\
\end{array}$ & $\begin{array}{c}125 \\
(45.0) \\
\end{array}$ & $\begin{array}{c}153 \\
(55.0) \\
\end{array}$ & \\
\hline & $\begin{array}{l}\text { Cannot be } \\
\text { corrected with } \\
\text { glasses }\end{array}$ & $\begin{array}{c}5 \\
(100.0)\end{array}$ & $0(0)$ & \\
\hline & $\begin{array}{l}\text { : Compariso } \\
\text { Among the S }\end{array}$ & $\begin{array}{l}\text { Refrc } \\
\text { ents }\end{array}$ & $\begin{array}{l}\text { by Ge } \\
\text { 70) }\end{array}$ & \\
\hline
\end{tabular}

*Fisher's exact test

\begin{tabular}{|c|c|c|c|c|c|}
\hline \multirow[b]{2}{*}{$\begin{array}{c}\text { Refractive Error } \\
\text { Type }\end{array}$} & \multicolumn{3}{|c|}{ Affected Side } & \multirow[b]{2}{*}{ Total } & \multirow[b]{2}{*}{$\%$} \\
\hline & $\begin{array}{c}\text { Right } \\
\text { Eye, } \\
\text { N (\%) }\end{array}$ & $\begin{array}{c}\text { Left } \\
\text { Eye, } \\
\text { N (5\%) }\end{array}$ & $\begin{array}{c}\text { Both } \\
\text { Eyes, } \\
\text { N (\%) }\end{array}$ & & \\
\hline Myopia & $\begin{array}{c}13 \\
(0.7)\end{array}$ & $\begin{array}{c}20 \\
(1.1)\end{array}$ & $\begin{array}{c}75 \\
(4.2)\end{array}$ & $\begin{array}{l}108 \\
(6.1)\end{array}$ & 34 \\
\hline Hypermetropia & $\begin{array}{c}9 \\
(0.5)\end{array}$ & $\begin{array}{c}6 \\
(0.3)\end{array}$ & $\begin{array}{c}41 \\
(2.3)\end{array}$ & $\begin{array}{c}56 \\
(3.2)\end{array}$ & 18 \\
\hline Astigmatism & $\begin{array}{c}18 \\
(1.0)\end{array}$ & $\begin{array}{c}27 \\
(1.5)\end{array}$ & $\begin{array}{l}110 \\
(6.2)\end{array}$ & $\begin{array}{l}155 \\
(8.8)\end{array}$ & 48 \\
\hline & $\therefore$ & $\begin{array}{l}\text { Type } \\
\text { nts ( }\end{array}$ & $\begin{array}{l}\text { efract } \\
70)\end{array}$ & Error & \\
\hline
\end{tabular}

\section{DISCUSSION}

Our study showed a prevalence of ocular morbidity of $17.7 \%$, which is similar to prevalence of $15.6 \%$ ocular morbidity in a study in Tanzania.[9], but lower than a study conducted in Shimla where the prevalence was reported to be 31.6\%.[10]
This may be due to difference between the study populations. Refractive error was the commonest ocular morbidity with a prevalence of $16.4 \%$, which is comparatively similar to that of studies conducted in Surat with a prevalence of $15.22 \% .[11], 15.8 \%$ in Chile.[12], $17.1 \%$ in Malaysia.[13], and $14.7 \%$ in urban school children of lowincome families in Kolkata.[14], but lower than the finding of prevalence of $23.67 \%$ refractive error in a study conducted at a Tertiary Eye Care Hospital in Kolkata.[15] However, the findings in this study are much higher than that of urban and rural Maharashtra of $5.46 \%$ and $2.63 \%$ respectively.[6] and the study from Pokhara City in Nepal of 6.43\%.[16] Astigmatism was the most common refractive error in this study accounting for $48 \%$ of all refractive errors. These findings are comparable with the prevalence of $52 \%$ of astigmatism in the Kampala study.[17] In contrast to our study, myopia is the most common refractive error in the Surat and urban Kolkata study.[11,13] This may be due to use of different operational definition and other demographic factors. A significant proportion of girls suffer from refractive error $(58 \%)$ as compared to boys (42\%), which is comparable to the Haryana and Kolkata study.[8,15] and also to the Rohtak study.[18] where higher prevalence of refractive errors was observed in girls $(73.53 \%)$ as compared to boys (73.53\%). It was concluded that high prevalence of ocular morbidity was observed in rural area of Manipur. The school eye screening program should be strengthened to reduce the prevalence of visual impairment due to refractive error and other ocular morbidities. Thus, a large number of visual impairment and blindness can be avoided.

\section{REFERENCES}

1. Woddell K. Spherical refraction for general eye workers. Commun Eye Health 2000;13(33):6-7.

2. Dondona R, Dondona L. Refractive error blindness. Bull World Health Organ 2001;79(3):237-43.

3. Danish Assistance to the National Programme for Control of Blindness. New Delhi, India: Vision screening in school children. Training module 1.

4. Gilbert C, Foster A. Childhood blindness in the context of VISION 2020-the right to sight. Bull World Health Organ 2001;79(3):227-32.

5. Negrel AD, Ellwein LB. More research needed to assess the magnitude of refractive errors world-wide. Commun Eye Health 2000;13(33):11-2.

6. Padhya AS, Khandekar R, Dharmadhikari $S$, et al. Prevalence of uncorrected refractive error and other eye problems among urban and rural school children. Middle East Afr J Ophthalmol 2009;16(2):69-74.

7. Uzma N, Kumar BS, Khaja Mohinuddin Salar BM, et al. A comparative clinical survey of the prevalence of refractive errors and eye diseases in urban and rural school children. Can J Ophthalmol 2009;44(3):328-33.

8. Sharma S, Vashisht BM, Kalhan M, et al. Magnitude of refractive errors among school children in a rural block of Haryana. The Internet Journal of Epidemiology 2009;6(2). DOI:10.5580/1e5f.

9. Wedner SH, Ross DA, Balira R, et al. Prevalence of eye diseases in primary school children in a rural area of Tanzania. Br J Ophthalmol 2000;84:1291-7. 
10. Gupta M, Gupta BP, Chauhan A, et al. Ocular morbidity prevalence among school children in Shimla, Himachal, North India. Indian J Ophthalmol 2009;57(2):133-8.

11. Basu M, Das P, Pal R, et el. Spectrum of visual impairment among urban female school students of Surat. Indian J Ophthalmol 2011;59(6):475-9.

12. Maul E, Barroso S, Munoz SR, et al. Refractive error study in children: results from La Florida, Chile. Am J Ophthalmol 2000;129(4):445-54.

13. Goh PP, Abqariyah Y, Pokharel GP, et al. Refractive error and visual impairment in school age children in Gombak District, Malaysia. Ophthalmology 2005;112(4):678-85.

14. Ghosh S, Mukhopadhay U, Maji D, et al. Visual impairment in urban school children of low-income families in Kolkata, India. Indian J Public Health 2012;56(2):163-7.
15. Biswas J, Saha I, Das D, et al. Ocular morbidity among children at a tertiary eye care hospital in Kolkata, West Bengal. Indian J Public Health 2012;56(4):293-6.

16. Niroula DR, Saha CG. Study on the refractive errors of school going children of Pokhara city in Nepal. Kathmandu Univ Med J 2009;7(25):67-72.

17. Kawuna M, Mayeku R. A survey of refractive errors among children in lower primary schools in Kampala district. African Health Sciences 2002;2(2):69-72.

18. Khurana AK, Sikka KL, Parmar IP, et al. Ocular morbidity among school children in Rohtak City. Ind J Pub Health 1984;28(4):217-20. 